\title{
Hemogram and Biochemical Reference Values for Brotogeris chiriri (Psittaciformes: Psittacidae)
}

Paula Damasceno Gomes (Corresponding author)

Wild Animals Department, Veterinary Hospital

Faculty of Agronomy and Veterinary, University of Brasília

L4 Norte, UnB - Asa Norte, DF, 70636-200

Tel: +5561981254005Ｅ-mail: damasceno94@gmail.com

Hedermy Christiem Cerqueira de Paula Tessari

Wild Animals Department, Veterinary Hospital

Faculty of Agronomy and Veterinary, University of Brasília

L4 Norte, UnB - Asa Norte, DF, 70636-200

Tel: +5561983308912Ｅ-mail: hedermy.cerqueira@gmail.com

Adriana Pereira Furtado

Laboratory of Veterinary Clinical Pathology, Veterinary Hospital

Faculty of Agronomy and Veterinary, University of Brasília

L4 Norte, UnB - Asa Norte, DF, 70636-200

Tel: +5561996926741Ｅ-mail: furtadoap.vet@gmail.com

Giane Regina Paludo

Laboratory of Veterinary Clinical Pathology, Veterinary Hospital

Faculty of Agronomy and Veterinary, University of Brasília

L4 Norte, UnB - Asa Norte, DF, 70636-200

Tel: +5561995567740Ｅ-mail: giane@unb.br

Líria Queiroz Luz Hirano 
Wild Animals Department, Veterinary Hospital

Faculty of Agronomy and Veterinary, University of Brasília

L4 Norte, UnB - Asa Norte, DF, 70636-200

Tel: +5561983408286Ｅ-mail: liriahirano@unb.br

\author{
Received: October 23, 2019 Accepted: December 11, 2019 \\ doi:10.5296/jbls.v11i1.15690ＵRL: https://doi.org/10.5296/jbls.v11i1.15690
}

\begin{abstract}
Despite the large distribution of the Yellow-chevroned Parakeet in Cerrado biome, there are few studies on biological parameters in this species. The lack of information on free-living parakeets is a limiting factor for establishing data on the health and conservation status of these species. The aim of this study was to standardize hemogram and blood biochemistry values for specimens of Brotogeris chiriri. Blood samples were collected from 21 young, clinically healthy and free-living specimens from the Cerrado biome. The mean, median, standard deviation and intervals were calculated for the following hematological parameters: packed cell volume (PCV), red blood cells, hemoglobin, mean corpuscular volume (MCV), mean corpuscular hemoglobin concentration (MCHC), leukocytes, heterophils, eosinophils, lymphocytes, monocytes and thrombocytes; and blood biochemistry parameters: uric acid, aspartate aminotransferase, alanine aminotransferase, gamma-glutamyl transferase, alkaline phosphatase, total protein and albumin. Lower values of hemoglobin, MCV and MCHC when compared to the erythrogram interval of species belonging to the same genus and family, as well as a lymphocytic leukogram. The parameters related to blood biochemistry showed differences for alkaline phosphatase, presenting higher means values; and alanine aminotransferase, total protein and albumin, presenting lower means values when compared to other psittacids. This is a pioneer study to establish hematological and biochemical values for Brotogeris chiriri in the Cerrado biome. The importance of developing further studies to determine specific parameters for psittacid species is emphasized, with special regards to the effects of different stages of development, habitats and condition.
\end{abstract}

Keywords: avian hematology, cerrado, conservation, psittaciformes

\title{
1. Introduction
}

The Yellow-chevroned parakeet (Brotogeris chiriri Vieillot 1818) is one of the most widespread small psittacid species in South America (del Hoyo et al., 1997; IUCN, 2018). Its geographic range includes most of Brazil, being abundant in the Cerrado biome and in urban environments.

Several species of the Psittacidae family occur in the Brazilian biomes, however, the availability of studies characterizing the biological data of free living specimens and 


\section{Macrothink}

Journal of Biology and Life Science ISSN 2157-6076 2020, Vol. 11, No. 1

individuals kept in captivity is still limited. This becomes relevant in a scenario in which $28 \%$ of psittacid species are being threatened. The lack of information, especially when considering clinical and laboratorial parameters, can be justified by the difficulty in obtaining samples and the innumerable variables (habitat, diet, age, sex) that may influence the results (Vaz et al., 2015; 2016).

The establishment and standardization of biological parameters facilitates the gathering of information concerning the health status and physiological conditions of the individuals. Additionally, simple and minimally invasive methods, such as laboratory evaluations, allow for an effective monitoring of the physiological, therapeutic, pathological, ecological and environmental dynamics of a given population (Vaz et al., 2016).

Demand for more specific biological data for several avian species has become a growing necessity for both wildlife medicine and in situ conservation programs, justifying the need for the development of further studies in this area. The aim of the present study was to describe the reference values for hemogram and blood biochemistry parameters of young, free living Brotogeris chiriri specimens from the Cerrado biome.

\section{Materials and Methods}

This study was authorized by the Biodiversity Authorization and Information System (SISBIO/IBAMA), under registration no. 62647-1, and approved by the Ethics Committee on the Use of Animals (CEUA) of the University of Brasília (UnB) number 57/2018.

Twenty-one young, healthy specimens of B. chiriri (Figure 1), aged ten to 12 weeks, without defined sex, were used in this study. The animals were screened in the Wild Animals Department of the Veterinary Hospital of UnB (HVet-UnB).

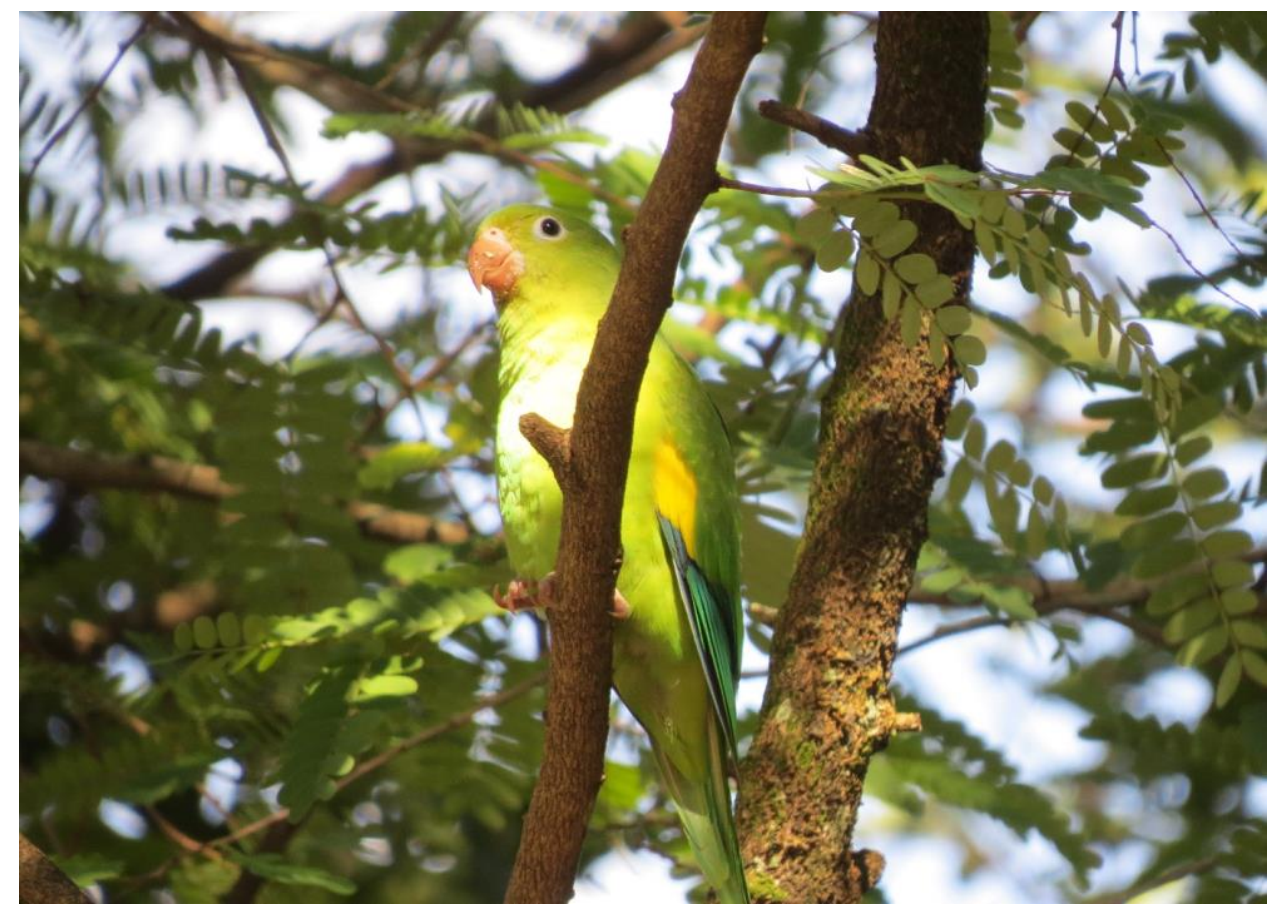

Figure 1. Yellow-chevroned Parakeet (Brotogeris chiriri) specimen 


\section{Macrothink}

The parakeets were submitted to individual physical evaluation and weighing, in order to verify their healthiness. Before the collections, they were kept without food for four hours, and were then physically and chemically restrained for blood collection. After physical immobilization, the animals were sedated with inhalation anesthesia, using isoflurane, by means of a universal vaporizer equipped with a mask.

The venipuncture site chosen was the right jugular vein (Figure 2), due to the large caliber and flow of this vessel. Antisepsis was performed with $70 \%$ alcohol and the blood collection was made with $1 \mathrm{~mL}$ syringes rinsed with $0.04 \mathrm{~mL}$ ethylenediamine tetraacetic acid (EDTA), with the samples then being stored into eppendorf flasks. The blood sample collected corresponded to $1 \%$ of the body weight of the animals. 


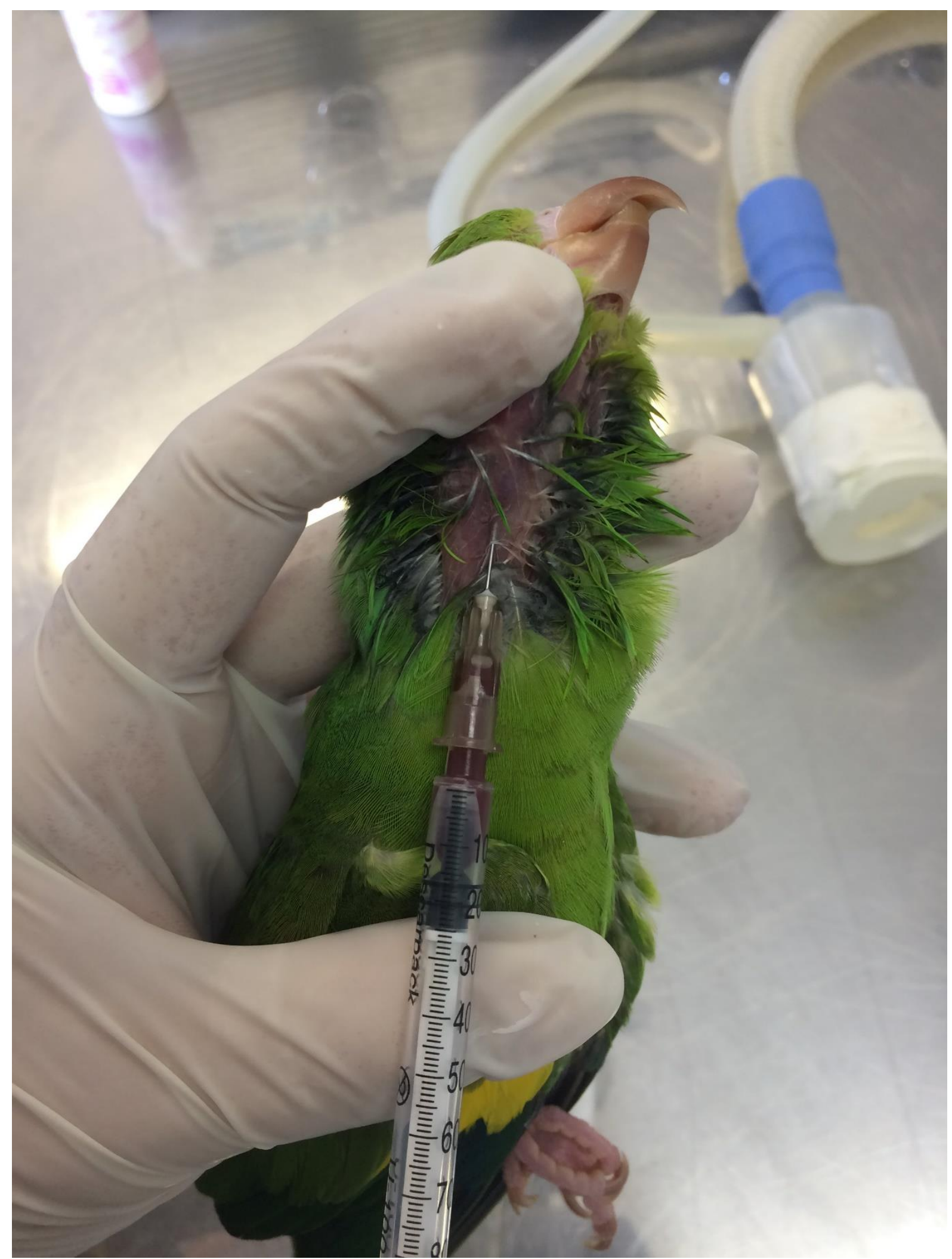

Figure 2. Blood collection in right jugular vein in a Yellow-chevroned Parakeet (Brotogeris chiriri) 


\section{Macrothink

The blood samples for hemogram and biochemistry were processed at the Laboratory of Veterinary Clinical Pathology of HVet-UnB. For blood cell counting, each sample was diluted in $2 \mathrm{~mL}$ of Natt and Herrick isotonic solution. After 15 minutes, a counting of red blood cells, leukocytes and thrombocytes were made in a Neubauer chamber.

For the hemoglobin measurement, $10 \mu \mathrm{L}$ of blood sample were diluted in $2.5 \mathrm{~mL}$ of Drabkin reagent and, after 5 minutes, that dilution was centrifuged at $3500 \mathrm{rpm}$ during 5 minutes for nuclei sedimentation, and processed in a semiautomatic biochemical analyzer. In addition, a microcapillary tube filled with blood was centrifuged for determination of packed cell volume (PCV) and total plasma proteins were measured by refractometry. A blood film stained with a kit for fast staining was used for differential leukocyte counting, cell morphology evaluation and hemoparasite screening.

For blood biochemical parameters, uric acid, alanine aminotransferase (ALT), aspartate aminotransferase (AST), alkaline phosphatase (ALP), gamma glutamyl transferase (GGT), total proteins (TP) and albumin were analyzed. After the hemogram analysis, the sample was centrifuged at $3500 \mathrm{rpm}$ for 5 minutes for red blood cell sedimentation and then the plasma was retrieved for biochemical analyses. All analyses were performed by the Cobas C-111 automatic analyzer (Roche Diagnostics do Brasil, São Paulo, SP).

The results were tabled and descriptive statistics were determined with the establishment of the mean, median, standard deviation, minimum and maximum values being made with the Microsoft Excel 2007 software. Data were previously tested for normality with a Shapiro-Wilk test, and for the presence of extreme values by observing the deviation, with the Bioestat 5.3 software (Ayres et al., 2007).

\section{Results}

The mean, median, standard deviation and interval (minimum and maximum) values of the hemogram and blood biochemical parameters for B. chiriri are shown in Tables 1 and 2, respectively. 
Table 1. Reference values of mean, median, standard deviation and interval (minimum and maximum) for the hemogram of young Brotogeris chiriri specimens

\begin{tabular}{|c|c|c|c|c|c|c|}
\hline Variable & SI Units & Mean & Median & SD & Min & Max \\
\hline $\mathrm{PCV}$ & $\%$ & 46.2 & 47.0 & 4.1 & 42.1 & 50.3 \\
\hline $\mathrm{RBC}$ & $10^{6} / \mu \mathrm{L}$ & 4.2 & 4.2 & 0.7 & 3.5 & 4.9 \\
\hline Hemoglobin & $\mathrm{g} / \mathrm{dL}$ & 10.1 & 10.4 & 1.5 & 8.6 & 11.6 \\
\hline $\mathrm{MCV}$ & $\mathrm{Fl}$ & 112.4 & 111.0 & 19.1 & 93.3 & 131.6 \\
\hline $\mathrm{MCHC}$ & $\mathrm{g} / \mathrm{dL}$ & 21.2 & 21.0 & 2.1 & 19.1 & 23.3 \\
\hline WBCs & $10^{3} / \mu \mathrm{L}$ & 15.6 & 15.0 & 6.0 & 9.7 & 21.6 \\
\hline Heterophils & $10^{3} / \mu \mathrm{L}$ & 5.44 & 5.10 & 2.73 & 2.70 & 8.18 \\
\hline Lymphocytes & $10^{3} / \mu \mathrm{L}$ & 8.87 & 8.46 & 3.58 & 5.28 & 12.4 \\
\hline Monocytes & $10^{3} / \mu \mathrm{L}$ & 0.95 & 0.91 & 0.59 & 0.40 & 1.44 \\
\hline Eosinophils & $10^{3} / \mu \mathrm{L}$ & 0.31 & 0.25 & 0.36 & 0 & 0.68 \\
\hline Heterophils & $\%$ & 34.71 & 34 & 12.26 & 22.4 & 47.0 \\
\hline Lymphocytes & $\%$ & 57.4 & 55.5 & 11.07 & 46.4 & 68.5 \\
\hline Monocytes & $\%$ & 5.95 & 6.0 & 2.54 & 3.4 & 8.5 \\
\hline Eosinophils & $\%$ & 1.86 & 1.50 & 1.93 & 0 & 3.8 \\
\hline Thrombocytes & & 26150 & 24000 & 8707.38 & 17442.62 & 34857.4 \\
\hline
\end{tabular}

SD (standard deviation), PVC (packed cell volume), RBC (red blood cells), MCV (mean corpuscular volume), MCHC (mean corpuscular hemoglobin concentration), WBC (white blood cells), SD (standard deviation), min (minimum), max (maximum). 


\section{MInstitute Macrothink}

Table 2. Reference values of mean, median, standard deviation and interval (minimum and maximum) for blood biochemical parameters of young Brotogeris chiriri specimens

\begin{tabular}{ccccccc}
\hline Variable & SI Units & Mean & Median & SD & Min & Max \\
\hline Uric acid & mg/dL & 4.00 & 3.65 & 1.92 & 2.1 & 5.9 \\
ALT & U/L & 2.79 & 3.00 & 0.71 & 2.1 & 3.5 \\
AST & U/L & 229 & 227.0 & 25.90 & 203.2 & 255.0 \\
ALP & U/L & 350.4 & 359.0 & 119.17 & 231.3 & 469.6 \\
GGT & U/L & 1.43 & 1.0 & 1.12 & 0.3 & 2.5 \\
TP & g/dL & 2.15 & 2.2 & 0.41 & 1.7 & 2.6 \\
Albumin & g/dL & 0.91 & 0.9 & 0.19 & 0.7 & 1.1 \\
\hline
\end{tabular}

ALT (alanine aminotransferase), AST (aspartate aminotransferase), ALP (alkaline phosphatase), GGT (gamma glutamyl transferase), TP (total proteins), SD (standard deviation), min (minimum), max (maximum).

\section{Discussion}

In the erythrogram evaluation, the reference range presented in this study, regarding the packed cell volume (PCV) and red blood cells (RBC) count, resemble the values described for species of the same genus, such as Brotogeris tirica (Silva, 2010) and Brotogeris pyrrhoptera (Hawkins et al., 2018). Conversely, for parameters such as hemoglobin, mean corpuscular volume (MCV) and mean corpuscular hemoglobin concentration (MCHC), the means and interval values were different from those cited in the literature for the genus (Silva, 2010; Hawkins et al., 2018), with lower values being reported in the present study. This emphasizes the need for more studies with different species, since there are significant variations within the same genus.

Additionally, several physiological variables can influence the determination of hematological parameters in a species, such as age, seasonality, reproductive period and habitat. However, it is important to emphasize that such factors affect only the concentration of hematological constituents and not the cellular morphology (Clark et al., 2009; Capitelli, 2013; Schimitd, 2014). The results found in this study can be considered a physiological aspect of the species, since there were no clinical alterations and no changes in cellular morphology, evidencing the absence of influence from possible pathological alterations.

Age is one of the most studied variables when concerning the standardization of biological parameters, and its influence is well documented for some species. It has been demonstrated 
that the progressive increase of hematological values occurs according to aging, with young birds typically exhibiting lower values than adults, which may justify the discrepancy of results between this and other studies (Clark et al., 2009).

Samour (2006) determined hemogram values for young specimens of Ardeotis kori during their development, with collections during the first ten months of the animal's lives. The results found for juveniles aged up to four months showed lower values of hemoglobin $(7.5 \pm$ $0.2 \mathrm{~g} / \mathrm{dL}$ ), which corroborates the findings of the present study, in which age may have influenced the determination of the parameters. Other species in which smaller values were also reported for younger animals were Chilean flamingos (Phoenicopterus chilensis) (Hawkey et al., 1984), White storks (Ciconia ciconia) (Montesinos et al., 1997) and Pheasants (Phasianus colchicus) (dos Santos Schmidt et al., 2007).

For the leukogram, the only parameter that exhibited lower values when compared to other Brotogeris species were the heterophil relative values (Table 2). The number of absolute lymphocytes was higher than the reference values reported for psittacids of the same genus (Silva, 2010; Hawkins et al., 2018).

In most species, the heterophils are the predominant leukocyte type. However, there are species in which the standard physiological conditions correspond to a predominance of lymphocytes. Psittacids of the genera Amazona and Melopsitaccus were cited as examples of this predominantly lymphocytic leukogram pattern (Harper, 1998; Mitchell \& Johns, 2008; Capitelli, 2013; Schimidt, 2014). Similar to mammals, young birds may experience a moderate increase in lymphocytes in response to an antigenic stimulation that occurs at this stage of life (Erf, 2008). However, additional studies may obtain different results according with to the animal's particularities and geographic occurrence.

The eosinophil values for $B$. chiriri also exhibited results above the mean and range described for other species of the same genus (Harrison, 2006; Silva, 2010; Hawkins et al., 2018). Eosinophilia in birds has been sporadically associated to gastrointestinal parasitism. However, several studies show that this pattern is inconsistent when experimental inductions of these parasite antigens are attempted. Other studies suggest that eosinophilia in these animals may occur in delayed-type hypersensitivity reactions, or even due to idiopathic causes (Campbell, 1994; Mitchel \& Johns, 2008; Doneley, 2010). In the present study, the animals were clinically healthy, without any gastrointestinal parasitism symptomatology. Therefore, the values reported here can be considered as physiological parameters for this species in the Cerrado.

Concerning the thrombocytes, the values found for $B$. chiriri fall within the range established for species of the genera Amazona, Psittacus and Cacatua (Samour, 2006; Capitelli, 2013).

The mean and range values for uric acid, ALT, AST, ALP, GGT, TP and albumin showed similarity when compared to analyses carried out in young specimens of other psittacid species, such as Cacatua alba, Ara ararauna and Eclectus roratus (Hawkins et al., 2018). When comparing the parameters from adult specimens, including B. pyrrhoptera, Aratinga spp. and Pyrrhura spp., it is possible to observe differences regarding ALT, TP and albumin, which are lower for B. chiriri (Hawkins et al., 2018). 
Contrastingly, the values of ALP are higher when compared to the parameters of adults of other species (Harrison, 2006; Hawkins et al., 2018). It is expected that the parameters found for ALP in the individuals in this study could exhibit high values, since production of this isozyme increases during osteoblast multiplication, resulting in high concentrations in the bones of developing animals (Schimitd, 2014; Hawkins et al., 2018).

Physiological factors such as age and stage of development are also significant in determining PT and albumin concentrations in birds (Harr, 2006). Maturity has been associated with increased TP values in several species. Lower values of total protein were found by Allgayer (2009) in young Anodorhynchus hyacinthinus. It is suggested that such decrease may be due to the rapid growth and increase of muscle mass, or to protein deficiency in the bird's diet during this phase (Allgayer, 2009). In addition, the progressive increase in total protein levels may be associated with elevated antibody concentrations (Lanzarot et al., 2005). Body temperature is another physiological variable that may be associated with nitrogen loss, increased adrenal activity and increased protein turnover, which results in a TP decrease (Hochleithner, 1994).

In relation to the lower values found for ALT when compared to adults of the same genus, it is known that this parameter is also influenced by age and increases in with the animal's maturity (Schimitd, 2014). This parameter is not considered particularly reliable for evaluation of pathological changes in birds, since it may increase because of any kind of tissue damage. Moreover, in some species, normal ALT activity values fall below the sensitivity threshold of many of the methods used (Doneley, 2010; Schimitd, 2014).

\section{Conclusion}

The results of the present study, when compared to the literature available for parakeets of the genus Brotogeris, report divergences for some hematological and biochemical parameters. It is suggested that these differences are physiological and mostly attributed to the individuals' age. Another characteristic inherent to the species diagnosed in the study was the predominantly lymphocytic leukogram pattern. The importance of the development of more studies with aiming to establish more specific parameters for psittacid species is emphasized, especially when concerning the effects different stages of development, different habitat and conditions.

\section{References}

Allgayer, M. C., Guedes, N. M. R., Chiminazzo, C., Cziulik, M., \& Weimer, T. A. (2009). Clinical pathology and parasitologic evaluation of free-living nestlings of the hyacinth macaw (Anodorhynchus hyacinthinus). Journal of wildlife diseases, 45(4), 972-981. https://doi.org/10.7589/0090-3558-45.4.972

Ayres, M., Ayres Júnior, M., Ayres, D. L., \& Santos, A. D. A. D. (2007). BioEstat: aplicações estatísticas nas áreas das ciências biomédicas. Ong Mamiraua. Belém, PA.

Campbell, T. W., Harrison, G. J., Harrison, L. R., \& Ritchie, B. W. (1994). Avian medicine: principles and application. Lake Worth (Fla): Wingers Pub, (Chapter 9). 
Capitelli, R., \& Crosta, L. (2013). Overview of psittacine blood analysis and comparative retrospective study of clinical diagnosis, hematology and blood chemistry in selected psittacine species. Veterinary Clinics: Exotic Animal Practice, 16(1), 71-120. https://doi.org/10.1016/j.cvex.2012.10.002

Clark, P., Boardman, W. S. J., \& Raidal, S. R. (2009). Physiological and pathological influences on the hematological characteristics of birds. Atlas of clinical avian hematology. Ames (IA): Wiley-Blackwell, 97-124.

Del Hoyo, J., Del Hoyo, J., Elliott, A., \& Sargatal, J. (1992). Handbook of the birds of the world (Vol. 1, No. 8). Barcelona: Lynx edicions.

del Pilar Lanzarot, M., Montesinos, A., San Andrés, M. I., Rodríguez, C., \& Barahona, M. V. (2001). Hematological, protein electrophoresis and cholinesterase values of free-living nestling peregrine falcons in Spain. Journal of Wildlife Diseases, 37(1), 172-178. https://doi.org/10.7589/0090-3558-37.1.172

Doneley, B. (2016). Avian medicine and surgery in practice: companion and aviary birds. Queensland (Au): CRC press, (Chapter 4). https://doi.org/10.1201/b19656

dos Santos Schmidt, E. M., Paulillo, A. C., Santin, E., Dittrich, R. L., \& de Oliveira, E. G. (2007). Hematological and serum chemistry values for the ring-necked pheasant (Phasianus colchicus): variation with sex and age. Int. J. Poult. Sci., 6, 137-139. https://doi.org/10.3923/ijps.2007.137.139

Erf, G. F. (2004). Cell-mediated immunity in poultry. Poultry science, 83(4), 580-590. https://doi.org/10.1093/ps/83.4.580

Harper, E. J., \& Lowe, B. (1998). Hematology values in a colony of budgerigars (Melopsittacus undulatus) and changes associated with aging. The Journal of nutrition, 128(12), 2639S-2640S. https://doi.org/10.1093/jn/128.12.2639S

Harr, K. E., Harrison, G. J., \& Lightfoot, T. L. (2006). Clinical Avian Medicine. Palm Beach, FL: Spix Publishing, (Chapter 23).

Harrison, G. J., \& Lightfoot, T. L. (2006). Avian hematologic reference ranges for clinically normal psittacines. Clinical Avian Medicine. Palm Beach, FL: Spix Publishing, p.1006-1008.

Hawkey, C., Hart, M. G., \& Samour, H. J. (1984). Age-related haematological changes and haemopathological responses in Chilean flamingos (Phoenicopterus chiliensis). Avian Pathology, 13(2), 223-229. https://doi.org/10.1080/03079458408418526

Hawkins, M. G., Guzaman, D. S. M., Beaufrere, H., Lennox, A., \& Carpenter, M. (2018). Exotic Animal Formulary (5th ed). St Louis (Mo): Elsevier Health Sciences (Chapter 5).

Hochleithner, M., Harrison, G. J., Harrison, L. R., \& Ritchie, B. W. (1994). Avian medicine: principles and application. Lake Worth (Fla): Wingers Pub, (Chapter 11).

IUCN BirdLife International 2018. Brotogeris chiriri. The IUCN Red List of Threatened Species 2018. Available: https://www.iucnredlist.org/species/22685963/130103839. 
Mitchell, E. B., \& Johns, J. (2008). Avian hematology and related disorders. Veterinary Clinics of North America: Exotic Animal Practice, 11(3), 501-522. https://doi.org/10.1016/j.cvex.2008.03.004

Montesinos, A., Sainz, A., Pablos, M. V., Mazzucchelli, F., \& Tesouro, M. A. (1997). Hematological and plasma biochemical reference intervals in young white storks. Journal of Wildlife diseases, 33(3), 405-412. https://doi.org/10.7589/0090-3558-33.3.405

Samour, J., Harrison, G. J., \& Lightfoot, T. L. (2006). Clinical Avian Medicine. Palm Beach, FL: Spix Publishing, (Chapter 22).

Schimidt, E. M. S., Cubas, Z.S., Silva, J. C. R., \& Catão-dias, J. L. (2014). Tratado de animais selvagens: medicina Veterinária (2nd ed). São Paulo (SP): Roca, (Capítulo 83).

Silva, G. (2010). Perfil hematológico de psitacídeos mantidos em cativeiro. Monografia (Graduação em Medicina Veterinária). Universidade Federal do Vale do São Francisco. Petrolina-PE. 67p.

Vaz, F. F., Locatelli-Dittrich, R., Beltrame, O. C., Sipinski, E. A. B., Abbud, M. C., \& Sezerban, R. M. (2016). Hematologic and biochemical values of wild red-tailed Amazon parrot (Amazona brasiliensis) nestlings with abnormal clinical examination in Rasa Island, Brazil. Journal of avian medicine and surgery, 30(4), 350-357. https://doi.org/10.1647/2015-119

Vaz, F. F., Locatelli-Dittrich, R., Sipinski, E. A., Abbud, M. C., Sezerban, R. M., Schmidt, E. M., ... Cavalheiro, M. L. (2015). Hematologic and total plasma protein values in free-living red-tailed Amazon parrot nestlings (Amazona brasiliensis) in Paraná State, Brazil. Journal of avian medicine and surgery, 29(3), 187-192. https://doi.org/10.1647/2014-050

\section{Copyright Disclaimer}

Copyright for this article is retained by the author(s), with first publication rights granted to the journal.

This is an open-access article distributed under the terms and conditions of the Creative Commons Attribution license (http://creativecommons.org/licenses/by/3.0/). 